\title{
Four new species of the Endogonaceae (Zygomycotina) from Poland
}

\author{
JANUSZ BEASZKOWSKI
}

\begin{abstract}
BŁASZKOWSKI, J. 1988: Four new species of the Endogonaceae (Zygomycotina) from Poland. - Karstenia 27: 37-42.

Four new species of vesicular-arbuscular mycorrhizal fungi from Poland, Glomus dominikii Błaszk., Acaulospora polonica Błaszk., A. gedanensis Błaszk., and A. thomii Błaszk. are described.
\end{abstract}

Janusz Btaszkowski, Department of Plant Pathology, Academy of Agriculture, Stowackiego 17, PL-71434 Szczecin, Poland

\section{Introduction}

The Endogonaceae are hardly known in Poland. Only one species, Glomus macrocarpum Tul. \& Tul., has been reported there (Eawrynowicz 1979). During the last four years I have studied the occurrence of endomycorrhizal fungi. Among the isolated species there are many which have been described earlier (Błaszkowski 1988). However, in 1985 and 1986 I collected specimens that differ from any known species. Their descriptions are presented below.

\section{Material and methods}

Soil samples collected from the rhizosphere of various plants were investigated. Spores were extracted by a wet-sieving and filtration technique (Koske \& Walker 1984). Spores were then mounted on microscope slides in polyvinyl alcohol lactophenol (Walker 1979), lactophenol, and Melzer's reagent. Wall descriptions and terminology are according to Walker (1983, 1985). A pot culture (Gilmore 1968) was used to indicate the type of mycorrhizac. Roots were stained after Phillips and Hayman (1970). All collections were made by the author. The holotype and other specimens are deposited in the Department of Plant Pathology (DPP), Academy of Agriculture, Szczecin, Poland.

Glomus dominikii Błaszkowski n. sp.

- Figs. 1, 9

Chlamydosporae in solo efformatae, albae, luteolae vel luteae, globosae vel subglobosae, (75-) 107 (-165) $\mu \mathrm{m}$ diam, raro ovoideae, $100 \times 150 \mu \mathrm{m}$, cum ornamento. Sporae tunica e stratis tribus; exteriore hyalino, rigido, (1.7-) 3 (-3.7) $\mu \mathrm{m}$ crasso, cum verrucis exiguis, 1.7-5.7 × 0.7-1.9 $\mu \mathrm{m}$; secundo hyalino, membranaceo, (0.2-) 0.7 (-1.2) $4 \mathrm{~m}$ crasso; interiore hyalino, membranaceo, (1.2-) 1.8 (-2.5) $\mu \mathrm{m}$ crasso. Hypha hyalina, 180-220 $\mu \mathrm{m}$ longa, (6.4-) 8.7 (-12.5) $\mu \mathrm{m}$ diam. - Holotype: Poland. Szczecin voiv., Kołbacz, under Trifolium pratense L., 10.VII.1985 J. Błaszkowski 256 (DPP). I have named this species in honour of Prof. T. Dominik, a long-time student of mycorrhizae in Poland.

Chlamydospores. Borne singly in the soil, white, slightly pink when immersed in water, becoming light yellow to orange-yellow with age, ornamented, globose to subglobose, (75-) $107(-165) \mu \mathrm{m}$ in diam, rarely ovoid, $100 \times 150 \mu \mathrm{m}$, with a single subtending hypha.

Spore wall structure. Of three layers (layers 1-3) in two groups (groups A, B). Group A, of a hyaline, unit, (1.7-) $3(-3.7) \mu \mathrm{m}$ thick outer layer (layer 1), ornamented with fine warts, $1.7-5.7 \times 0.7-1.9 \mu \mathrm{m}$. Group B, of a hyaline, smooth, membranous, (0.2-) $0.7(-1.2) \mu \mathrm{m}$ thick layer (layer 2), tightly adhering to a hyaline, smooth, membranous, (1.2-) 1.8 $(-2.5) \mu \mathrm{m}$ thick innermost layer (layer 3).

Subtending hypha. Hyaline, straight or slightly 
recurvate, 180-220 $\mu \mathrm{m}$ long, (6.4-) $8.7(-12.5) \mu \mathrm{m}$ wide, with walls (1.2-) $1.5(-1.9) \mu \mathrm{m}$ thick at the spore base, without a septum; usually slightly constricted at the attachment.

The wall 1 turns yellow, wall 2 is not reacting, and wall 3 stains red or orange-red in Melzer's reagent. Differs from G. scintillans Rose \& Trappe (Rose \& Trappe 1980) in the colour and size of the spores, by having a thinner middle layer, and by staining in Melzer's reagent.

Mycorrhizal associations. Unknown.

\section{Material examined}

Poland. Szczecin voiv.: Kołbacz, under Trifolium pratense, 10.VII.1985 J. Błaszkowski 256-260. Prusinowo, under Fragaria vesca, 5.VIII.1985 J. Błaszkowski 266-268. Czciradz, under T. pratense, 27.VIII.1985 J. Błaszkowski 271-280. Nowogard, under Lupinus luteus, 5.VIII.1985 J. Błaszkowski 281-285. Kamień Pomorski, under Pisum arvense, 25.VII.1985 J. Błaszkowski 286. Brzozowo, under Triticum vulgare, 25.VII.1985 J. Błaszkowski 287. Przybierów, under Secale cereale, 25.VII.1985 J. Błaszkowski 288. Trzebiatów, under Allium porrum, 5.VIII.1985 J. Błaszkowski 289. Gdañsk voiv., Chynów, under Avena sativa, 20.VII.1985 J. Błaszkowski 261-265. Zielona Góra voiv., Lasocin, under Zea mays, 27.VIII.1985 J. Błaszkowski 269-270. Zamość voiv., Zwierzyniec, under Festuca rubra, 18.X.1986 J. Błaszkowski 290-291.

\section{Acaulospora polonica Błaszkowski n. sp.} -Figs. 2, 9

Azygosporae singulares in solo efformatae, sessiles; terminatione inflata globosa vel subglobosa, 60$90 \mu \mathrm{m}$ diam; hypha interjacens spora et terminationis 40-70 $\mu \mathrm{m}$. Sporae hyalinae, albidae, globosae vel subglobosae, (80-) 94 (-115) um diam, raro ovoideae, $115 \times 80 \mu \mathrm{m}$. Sporae tunica e stratis quattuor; exteriore hyalino, rigido, (1.5-) $1.9(-2.3) \quad \mu m$ crasso; secundo hyalino, membranaceo, ad $0.5 \mu \mathrm{m}$ crassum; tertio et quarto hyalino, membranaceo, (0.5-) 0.8 (-1) um crasso. - Holotype: Poland. Gdańsk voiv., Hel, about $200 \mathrm{~m}$ from the Baltic Sea, under Thuja occidentalis L., 21.VIII.1985 J. Błaszkowski 95 (DPP). I have named this species referring to the country in which it was first noted.

Azygospores. Borne singly in the soil, hyaline, whitish, smooth, globose to subglobose, (80-) 94 $(-115) \mu \mathrm{m}$ in diam, rarely ovoid, $115 \times 80 \mu \mathrm{m}$, sessile on a hypha tapering to a globose to subglobose swollen hyphal terminus, $60-90 \mu \mathrm{m}$ in diam; hyphal terminus contents hyaline; terminus wall $0.7-$ $1 \mu \mathrm{m}$ thick; distance between the hyphal terminus and the spore 40-70 $\mu \mathrm{m}$; hyphae at the point of the spore attachment $8-12.5 \mu \mathrm{m}$ in diam; in maturity the terminus empties and collapses.
Spore wall structure. Of four layers (layers 1-4) in three groups (groups A, B, C). Group A, of a hyaline, unit, (1.5-) $1.9(-2.3) \mu \mathrm{m}$ thick outer layer (layer 1). Group B, of a hyaline, membranous, up to $0.5 \mu \mathrm{m}$ thick layer (layer 2). Group $\mathrm{C}$, of two hyaline, membranous, (0.5-) $0.8(-1) \mu \mathrm{m}$ thick, adhering layers (layers 3,4 ).

Spores filled with hyaline droplets, and not reacting in Melzer's reagent. Four species of Acaulospora, A. trappei Ames \& Lind. (Ames \& Linderman 1976), A. delicata Walker, Pfeiffer \& Bloss (Walker et al. 1986), A. nicolsonii Walker, Reed \& Sanders (Walker et al. 1984), and A. longula Spain \& Schenck (Schenck et al. 1984) produce hyaline or subhyaline spores that could be confused with those of A. polonica. A. trappei forms slightly smaller (42$99 \times 42-70 \mu \mathrm{m})$ and 1-layered spores. The spore wall of A. delicata is also 4-layered but the layers are of different types of which the innermost one stains orange-red in Melzer's reagent. Spores of A. nicolsonii are considerably larger $(99-198 \times 109-218 \mu \mathrm{m})$ and have a different wall structure (4-layered with evanescent, laminate, unit, and membranous layers). A. longula has 5-layered spore wall, stains light purple in Melzer's reagent, and forms spores at greater distance (100-200 $\mu \mathrm{m})$ from its hyphal terminus.

Mycorrhizal associations. Unknown.

Material examined

See the type, and J. Błaszkowski 96-136 (isotypes, DPP).

\section{Acaulospora gedanensis Błaszkowski n. sp.} - Figs. 3, 9

Azygosporae singulares in solo efformatae, sessiles; terminatione inflata globosa vel subglobosa, 60 $70 \mu \mathrm{m}$ diam; hypha interjacens spora et terminationis 50-60 $\mu \mathrm{m}$. Sporae pallide luteae vel luteobrunneae, globosae vel subglobosae, (55-) 65 (-75) $\mu \mathrm{m}$ diam. Sporae tunica e stratis quinque; exteriore hyalino, ad $0.5 \mu \mathrm{m}$ crassum; secundo luteo vel pallido brunneo, laminato, (2.5-) 3.6 (-4.3) $\mu \mathrm{m}$ crasso; tertio ad quinque hyalina, membranacea, ad $0.5 \mu \mathrm{m}$ crassum. - Holotype: Poland. Gdańsk voiv., Chałupy, about $500 \mathrm{~m}$ from the Baltic Sea, under Festuca ovina L., 23.VIII.1985 J. Błaszkowski 137 (DPP). I have named this species referring to the voivodeship in which it was noted.

Azygospores. Single in the soil, pale yellow to yellow-brown, globose to subglobose, (55-) 65 $(-75) \mu \mathrm{m}$ in diam, sessile on a hypha tapering to a globose to subglobose swollen hyphal terminus, 60-70 $\mu \mathrm{m}$ in diam; hyphal terminus contents hyaline, terminus wall $0.5 \mu \mathrm{m}$ thick; distance between the 

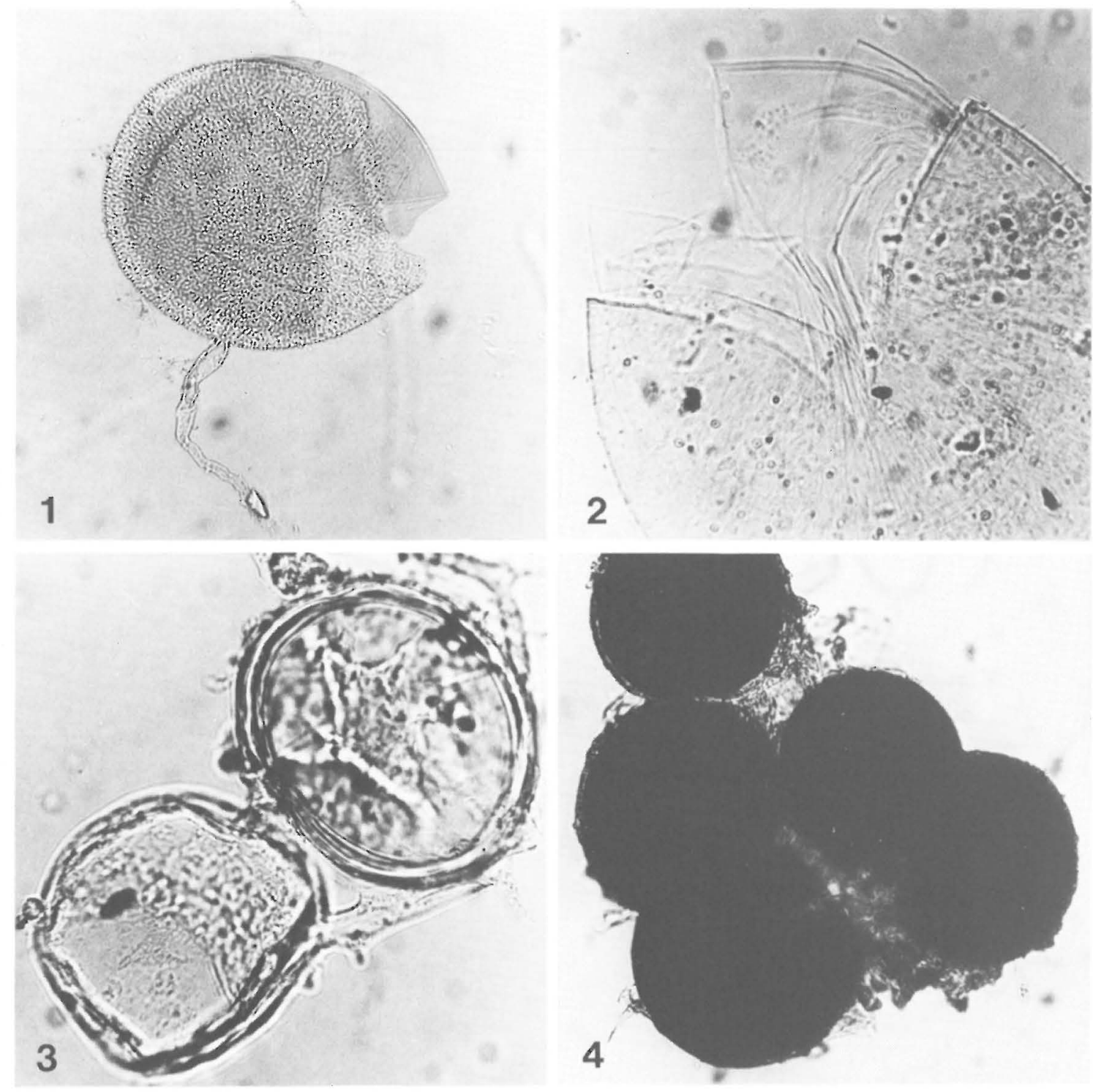

Figs. 1-4. Micrographs of the Endogonaccae. - 1: Glomus dominikii, a crushed spore in Melzer's reagent; the innermost layer is stained dark (x 236). - 2: Acaulospora polonica, a crushed spore in lactophenol showing the wall strucutre $(x 559) .-3: A$ gedanensis, a spore with empty hyphal terminus (x 568). - 4: A. thomii, a sporocarp in water (x 109).

hyphal terminus and the spore $50-60 \mu \mathrm{m}$; in maturity the terminus empties and collapses.

Spore wall structure. Of five layers (layers $1-5$ ) in two groups (groups A, B). Group A, of a hyaline, sloughing, up to $0.5 \mu \mathrm{m}$ thick outer layer (layer 1), adhering to a yellow to pale brown, laminate, $(2.5-)$ $3.6(-4.3) \mu \mathrm{m}$ thick layer (layer 2). Group B, of three hyaline, separating membranous layers (layers $3-5)$, each up to $0.5 \mu \mathrm{m}$ thick.
A. gedanensis is very similar to $A$. rugosa Morton, $A$. dilatata Morton, and A. lacunosa Morton (Morton 1986). A. rugosa forms brighter (subhyaline to straw-coloured) and slightly larger (49-92$118 \mu \mathrm{m}$ in diam) spores, their wall contains 5 layers of different types the innermost of which stains dark purple in Melzer's reagent. Spores of A. dilatata are larger (78-106-130 $\mu \mathrm{m}$ in diam) and covered with minute pits, have a different wall structure (5-layered 

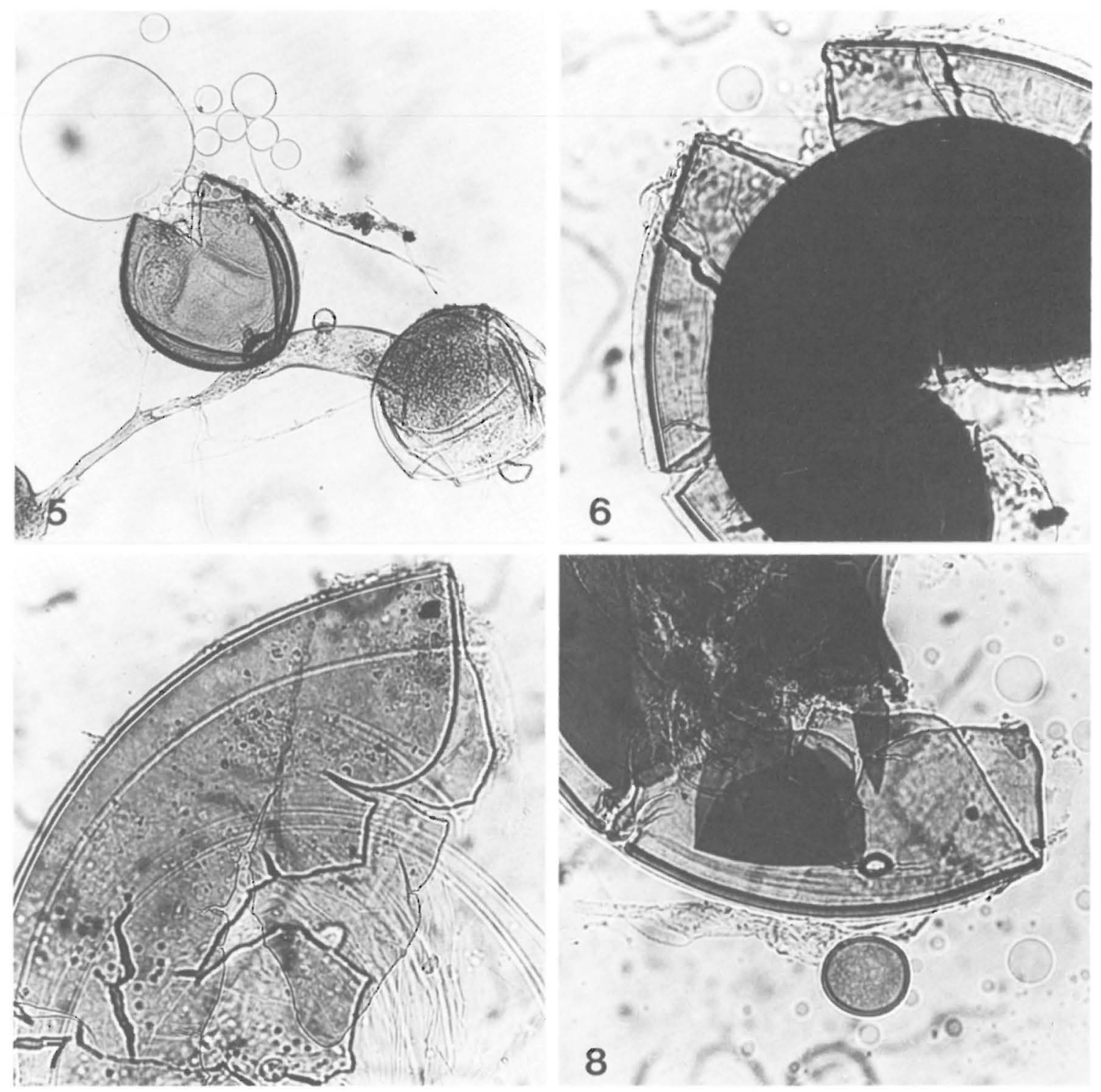

Figs. 5-8. Crushed spores of Acaulospora thomii. - 5: With empty hyphal terminus, in polyvinyl alcohol lactophenol (x 132). - 6: In Melzer's reagent, showing the thick hyaline layer 1 adhering to layer 2 and dark-stained innermost layer ( $x$ 631). - 7: In polyvinyl alcohol lactophenol, showing the wall structure ( $x$ 344). - 8: In Melzer's reagent, with dark-stained vesicular structurc (x 652).

in 3 groups) and stain in Melzer's reagent. A. lacunosa also produces larger spores $(98-131-186 \mu \mathrm{m}$ in diam) which have a different wall structure (5-layered in 3 groups, the outermost layer is pitted) and stain dark purple in Melzer's reagent.

Mycorrhizal associations. Unknown.

Material examined

See the type, and Błaszkowski 138-154 (isotypes, DPP).
Acaulospora thomii Błaszkowski n. sp.

- Figs. 4-9

Azygosporae singulares in solo efformatae vel in sporocarpiis, $160-520 \times 300-700 \mu \mathrm{m}$, sine peridio, $e$ sporis duobus ad quinque. Sporae sessiles; terminatione inflata globosa vel subglobosa, (170-) 186 (-210) $\mu \mathrm{m}$ diam; hypha interjacens spora et terminationis (70-) $136(-250) \mu \mathrm{m}$. Sporae fuscae 


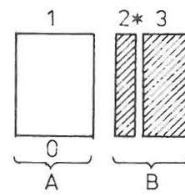

Glomus

dominikii

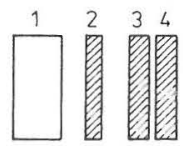

Acaulospora

polonica
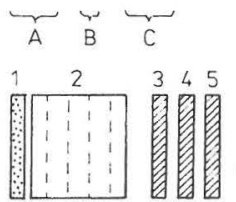

Acaulospora

gedanensis

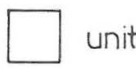

unit

$\begin{array}{llll}1 & 1 & \text { laminate } \\ 1 & 1 & \\ 1 & & \end{array}$

membranous

evanescent
Fig. 9. Murographs of four new species of the Endogonaceae. The numbers indicate each wall in order from outer to inner wall; the letters indicate wall groups. ${ }^{*}=$ walls very difficult to discern; 0 = wall surface omamented.

A

B
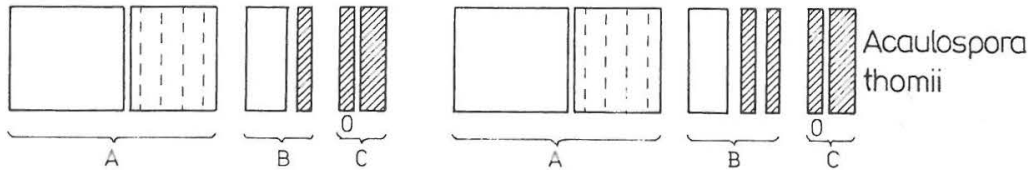

vel nigrae, globosae vel subglobosae, (150-) 185 (-240) um diam, raro ovoideae, $200 \times 240 \mu \mathrm{m}$. Sporae tunica e stratis sex vel septem; exteriore hyalino, rigido, (2.5-) 4.4 (-6.5) $\mu \mathrm{m}$ crasso; secundo luteo-brunneo vel brunneo, laminato, (2.5-) 3.3 (-4) $\mu \mathrm{m}$ crasso; tertio hyalino, rigido, 1.3-1.8 $\mu \mathrm{m}$ crasso; quarto ad quinque hyalinum, membranaceum, ad 0.5 um crassum; sex hyalino, membranaceo, granulato, ad $0.5 \mu \mathrm{m}$ crassum; septem hyalino, membranaceo, (0.5-) 0.9 (-1.3) um crasso. Holotype: Poland. Zielona Góra voiv., Bolesławiec, under Triticum aestivum, 17.VIII.1985 J. Błaszkowski 352 (DPP). I have named this species in honour of my son, as a present for his first birthday.

Azygospores. Formed singly in the soil or occasionally in regular or irregular-shaped, small, 160$520 \times 300-700 \mu \mathrm{m}$ sporocarps, without a peridium, with 2-5 spores. Spores dark brown to black in water, olive-brown to brown in lactophenol, globose to subglobose, (150-) $185(-240) \mu \mathrm{m}$ in diam, borne laterally on a hypha, $22.5-45 \mu \mathrm{m}$ wide at the attachment, tapering to a globose to subglobose swollen hyphal terminus, 170-210 $\mu \mathrm{m}$ in diam; hyphal terminus contents hyaline to light yellow; terminus wall $2.5-4.5 \mu \mathrm{m}$ thick; distance between the hyphal terminus and the spore $70-250 \mu \mathrm{m}$; in maturity the terminus empties and collapses.

Spore wall structure. Of six or seven layers (layers 1-7) in three groups (groups A, B, C). Group A, of a hyaline, unit, (2.5-) $4.4(-6.5) \mu \mathrm{m}$ thick outer layer (layer 1), adhering to a yellowbrown to brown, laminate, (2.5-) $3.3(-4) \mu \mathrm{m}$ thick layer (layer 2). Group B, of a hyaline, unit, (1.3-) $1.5(-1.8) \mu \mathrm{m}$ thick layer (layer 3 ), and one or two hyaline, up to $0.5 \mu \mathrm{m}$ thick membranous layers (layers 4,5 ). Group $\mathrm{C}$, of a hyaline, membranous, up to $0.5 \mu \mathrm{m}$ thick layer (layer 6), with 'beaded' appearance, adhering to a hyaline, membranous, (0.5-) 0.9 (-1) $\mu \mathrm{m}$ thick innermost layer (layer 7).

A. thomii closely resembles $A$. sporocarpia Berch (Berch 1985) and A. laevis Gerd. \& Trappe (Gerdemann \& Trappe 1974). A. sporocarpia forms larger sporocarps $(2.5 \times 1.5 \times 1.5 \mathrm{~cm})$ and the spores have a two-layered wall, the outer of which is thinner $(2.5-5 \mu \mathrm{m})$ than the inner one $(7-15 \mu \mathrm{m})$. A laevis produces spores singly in the soil and has a threelayered spore wall of which the outer sloughs.

In the sporocarps of $A$. thomii one can sometimes find thin-walled 'vesicle-like' structures (Fig. 8). They stain rapidly in Melzer's reagent, changing from hyaline to orange-pink. Similar structures occur in sporocarps of $A$. appendicula Schenck et al. and $A$. sporocarpia. As discussed by Schenck et al. (1984), these structures seem to be a feature that links species of Acaulospora and Glomus.

Mycorrhizal associations. Forming vesiculararbuscular mycorrhizal infections with Triticum aestivum and Zea mays in the pot culture.

Material examined

See the type, and J. Błaszkowski 353-383 (isotypes, DPP). 


\section{References}

Ames, R.N. \& Linderman, R.G. 1976: Acaulospora trappei, sp. nov. - Mycotaxon 3: 565-569.

Berch, S.M. 1985: Acaulospora sporocarpia, a new, sporocarpic species, and emendation of the genus Acaulospora (Endogonaceae, Zygomycotina). - Mycotaxon 23: 409418.

Błaszkowski, J. 1988: Z badań nad wystepowaniem Endogonaceae w Polsce. - Biul. Lubel. Tow. Nauk. (in press).

Gerdemann, J.W. \& Trappe, J.M. 1974: The Endogonaceae in the Pacific Northwest. - Mycologia Memoirs 5: $1-76$.

Gilmore, A.E. 1968: Phycomycetous mycorrhizal organisms collected by open-pot culture methods. - Hilgardia 39: 87-105.

Koske, R.E. \& Walker, C. 1984: Gigaspora erythropa, a new species forming arbuscular mycorrhizae. - Mycologia 76: 250-255.

Ławrynowicz, M. 1979: Endogonales, kłebiankowe. - In: Skirgiełło, A., Zadara, M. \& Ławrynowicz, M., Grzyby 10: 273-295. Warszawa \& Kraków.

Morton, J.B. 1986: Three new species of Acaulospora (Endogonaceae) from high aluminium, low $\mathrm{pH}$ soils in West Virginia. - Mycologia 78: 641-648.

Phillips, J.M. \& Hayman, D.S. 1970: Improved procedures for clearing roots and staining parasitic and vesicular-arbuscular mycorrhizal fungi for rapid assessment of infection. - Trans. British Mycol. Soc. 55: 158-161.

Rose, S.L. \& Trappe, J.M. 1980: Three new endomycorrhizal Glomus spp. associated with actinorrhizal shrubs. - Mycotaxon 10: 413-420.

Schenck, N.C., Spain, J.L., Sieverding, E. \& Howeler, R.H. 1984: Several new and unreported vesicular-arbuscular mycorrhizal fungi (Endogonaceae) from Colombia. - Mycologia 76: 685-699.

Walker, C. 1979: The mycorrhizast and the herbarium: the preservation of specimens from VA mycorrhizal studies. - In: Program and Abstracts, 4th North American Conference on Mycorrhiza, June 24-28, 1979, Colorado State Univ., p. 117 (unnumbered). Mimeo. Fort Collins, Colorado.

- 1983: Taxonomic concepts in the Endogonaceae: spore wall characteristics in species descriptions. - Mycotaxon 18: 443-455.

- 1985: Taxonomic concepts in the Endogonaceae 2. A fifth morphological wall type in endogonaceous spores. Mycotaxon 25: 95-99.

Walker, C., Reed, L.E. \& Sanders, F.E. 1984: Acaulospora nicolsonii, a new endogonaceous species from Great Britain. - Trans. British Mycol. Soc. 83: 360-364.

Walker, C., Pfeiffer, C.M. \& Bloos, H.E. 1986: Acaulospora delicata sp. nov. - an endomycorrhizal fungus from Arizona. - Mycotaxon 25: 621-628.

Accepted for publication on 25 August 1987 